\title{
Improving the Vegetative Growth and Chemical Contents of Coriander (Coriandrum sativum L.) Plant by Using Moringa Leaf Extract. Omaima M. Abd-ElKafie ${ }^{1}$; Mahassen M. Sidky ${ }^{2}$; M. M. Kasem ${ }^{1}$ and Shaimaa M. Abd-ElBaki ${ }^{1}$ ${ }^{1}$ Veget. \& Floric. Dept., Fac. Agric., Mansoura Univ. \\ ${ }^{2}$ Hort. Res. Inst. Agric. Res. Center
}



\section{ABSTRACT}

This study was conducted to enhance the vegetative growth, fruits yield and chemical constituents of the coriander plant, in a trial to reducing the residual effects of the chemical fertilizers. Two methods for moringa leaf extract (cold or boiled extract) with different dilutions $(25,50,75$ and $100 \%)$ beside the distilled water as the control were used. The results cleared that the superior plant dry weight, N, P and K\% in leaves were recorded by using the boiled MLE at $100 \%$. In addition, the heaviest seed index (weight of 1000 fruits) was recorded by using the boiled MLE at 75\%. In addition the maximum essential oil percentage was recorded by using 100\% from the boiled or the cold MLE and linalool was the main component in the essential oil. Keywords: moringa leaf extract (MLE), coriander and methods of leaf extract.

\section{INTRODUCTION}

Coriander (Coriandrum sativum L.) belongs to the family Apiaceae. It is an aromatic herb, annual medicinal and spice plant, cultivates in the winter or the summer, depending on the climatic conditions and it is native to Mediterranean regions. Its cultivation is widespread in many countries surround the world. The traditional uses of coriander plants are culinary or medicinal based on the plant green herb or the dry fruits Ramadan and morsel (2002). Coriander fruit considered a usable raw material, in the applied therapeutics such as a stimulant for digestion, and improving the flavor of many dishes. Fruit essential oil is the main bioactive compound of coriander, which being a mixture of many terpenes, from which the greatest significance has linalool and geraniol Smallfield et al., (2001) and valuable raw materials in the perfume industry. It has been recommended for loss of appetite, dyspeptic complaints, convulsion, indigestion, insomnia, 3 carminative, diuretic, rheumatism, against worms tonic and stomachic. Moreover, the essential oils possess antioxidant anti-diabetic, anti-bacterial, anti-mutagenic activities and anti-cancerous Melo et al., (2003).

Moringa is a very important plant having miscellaneous allelopathic potential Fuglie (1999). Its water extract could enhance or improve the plant growth, if it applied as a foliar spray with low concentrations Phiri (2010).This promoting effect may be due to its content from various second metabolites or allelochemicals such as ascorbates, phenols Foidle et al., (2001) or it's the content of natural cytokinins (zeatin) Fuglie (2000). Moreover, its leaves had been reported to contain $7 \mathrm{x}$ the Vitamin $\mathrm{C}$ of Oranges, $4 \mathrm{x}$ the Calcium of Milk, $4 \mathrm{x}$ the Vitamin A of Carrots, $3 \mathrm{x}$ the Potassium of Bananas, and $2 \mathrm{x}$ the Protein of Yogurt) Fuglie et al., (1999). In addition, it considers a big house store from a lot of minerals like $\mathrm{K}, \mathrm{Ca}$ and $\mathrm{Fe}$ that makes it an excellent crop growth promoter. Also, moringa has quercetin, b-sisterol, caffeoylquinic acid and kaempferol which produced the antibacterial and antifungal activities Anjorin et al., (2010). The main advantage of these natural fertilizers is that they do not pollute the soil and also do not show any negative effect on the environment and human health.

So the aim of this investigation to study the effects of moringa leaf extract as biotic elicitor under different diluted concentrations to enhance the vegetative growth, fruits yield and chemical constituents of the coriander plant, in a trial to reduce the residual effects of the chemical fertilizers.

\section{MATERIALS AND METHODS}

This study was carried out at the nursery of ornamental plants Fac. of Agric. Mansoura Univ. during $2013 / 2014$ and $2014 / 2015$ seasons to investigate the response of coriander plant to the foliar application of two water extract types of moringa (Moringa oleifera L.) leaf.

\section{1: Plant Material}

Coriander seeds were obtained from a local market in El-Mansoura City. The experiment was achieved on rows of $70 \mathrm{~cm}$ wide and $10 \mathrm{~m}$ length for each treatment. Space between every two hills was 25 $\mathrm{cm}$ and uncultured row remained between each two treatments. Each treatment consists of three replicates, each contained five hills. A total nine cultured rows consisted all the experiment treatments. After the full germination, hills were thinned to approximately four plants per hill when seedlings reached approximately $10 \mathrm{~cm}$ in height. the process of irrigation was performed as usual with adding a basal NPK (20:20:20) after 2 weeks from the full germination.

\section{2: Moringa leaf extracts (MLE) preparation.}

Two methods for moringa leaf extracts were conducted. Since fresh moringa leaves $(1 \mathrm{~kg})$ of mature trees were collected, then leaves were washed and mixed with 1 liter distilled water by an electric blender, this extract was diluted with distilled water at a ratio of 1:30 (w/v) Nouman et al., (2012). Half of the previous extract was boiled. On the other side, the other one from the previous extract preparation were used except that it does not boil and kept in the refrigerator at $4^{\circ} \mathrm{C}$ for $24 \mathrm{~h}$. Then, the two extracted leaves were filtrated through sterilized cheesecloth and their chemical contents were analyzed and shown in Table (2). Finally, four diluted concentrations from each extract (boiled and cold) were prepared with the control one (distilled water), then it sprayed directly on the plants.

\section{3: Experimental Design}

A total nine treatments were arranged in a complete randomize block design with 3 replicates, as two water extract type of moringa leaves (boiled and cold extract) were used at four concentrations $(25,50$, 75 and $100 \%$ ), plus the control (distilled water) as a 
foliar application which sprayed three times, at 30, 45 and 60 days after sowing.

Table 1. Chemical analysis of moringa leaf extract.

\begin{tabular}{lcccc}
\hline $\begin{array}{l}\text { Sample } \\
\text { Method }\end{array}$ & Conc. & $\mathbf{N}$ & $\mathbf{~} \mathbf{P} / \mathbf{l}$ & $\mathbf{K}$ \\
\hline \multirow{4}{*}{ Cold } & $25 \%$ & 27.3 & 4.66 & 53.4 \\
& $50 \%$ & 48.2 & 8.95 & 107.8 \\
& $75 \%$ & 71.4 & 12.99 & 153.6 \\
& $100 \%$ & 92.6 & 17.38 & 198.2 \\
\hline \multirow{3}{*}{ Boiled } & $25 \%$ & 31.8 & 6.08 & 60.1 \\
& $50 \%$ & 56.3 & 11.22 & 115.9 \\
& $75 \%$ & 56.9 & 17.05 & 176.1 \\
& $100 \%$ & 109.7 & 21.65 & 227.4 \\
\hline
\end{tabular}

Chemical analysis of MLE was performed for determining its contents (Table1) and the soil sample also was analyzed and presented in Table (2).

Table 2. Chemical and mechanical analysis of the experimental soil.

\begin{tabular}{lcc}
\hline Items & & Value \\
\hline & Coarse sand & 3.22 \\
& Fine sand & 21.37 \\
Mechanical analysis (\%) & Silt & 43.25 \\
& Clay & 32.16 \\
& Texture class Sandy Clay loam \\
\hline E.C. dS.m ${ }^{-1}(1: 5)$ & & 1.05 \\
pH(1:2.5) & & 7.87 \\
S.P\% & & 48.5 \\
O.M\% & & 1.62 \\
CaCO $\%$ & & 3.77 \\
\hline \multirow{2}{*}{ Available $(\mathrm{mg} / \mathrm{kg})$} & $\mathrm{N}$ & 48.2 \\
& $\mathrm{P}$ & 4.35 \\
& $\mathrm{~K}$ & 1.85 \\
\hline
\end{tabular}

4: Data recorded

Vegetative growth characteristics; Plant height $(\mathrm{cm})$, branches number/hill and herb dry weights $(\mathrm{g}) / \mathrm{hill}$ were determined

Fruit parameters; umbels number/hill, fruits yield (g)/hill and seed index (weight of 1000 fruits).

Chemical determinations; $\mathrm{N}, \mathrm{P}, \mathrm{K} \%$, total carbohydrates in the plant tissues at the start of the flowering stage, beside the total chlorophyll were measured. The Nitrogen was determined according to AOAC (1984), phosphorus was estimated according to Jackson (1973) and potassium was determined according to Peterburgski (1968). Also, the total carbohydrates $(\%)$ in leaves were determined according to the method described by Sadasivam and Manickam (1996). Finally, the total chlorophyll in leaves were determined according to Mackinney (1941).

Essential oil determinations: The essential oil percentage was calculated as follows :

Volume of oil in graduated tube $(\mathrm{ml})$

Oil percentage $=$ - -

For determining the essential oil\% dried fruits were subjected to the hydro distillation by using the modified Clevenger traps in British pharmacopeia (2000)

Essential oil constituents (\%)

The volatile oil obtained from the dried fruits of five treatment samples (control, $75 \%$ cold, $100 \%$ cold, $75 \%$ boiled and $100 \%$ boiled MLE) in the second season only was analyzed using Ds Chrom6200Gas Chromatograph,

\section{5: Statistical analysis}

Data were subjected to analysis of variance (ANOVA) using Genstat v 11.1, 2008. Mean comparisons were performed by using the least significant differences methods (L.S.D), according to Gomez and Gomez (1984). A significant level of 0.05 was adopted for all statistical analysis for both seasons.

\section{RESULTS AND DISCUSSION}

\section{1: Vegetative growth parameters}

Data in Table (3) indicate that applying the foliar spray of the cold moringa leaf extract at concentration of $100 \%$ produced the tallest plant height than all of the other treatments, since it recorded $88.67 \mathrm{~cm}$, during the first season, followed by the values of 85.00 and $85.33 \mathrm{~cm}$ for coriander plants which sprayed with the cold and boiled MLE at 50\%. On contrast, the control plants which treated with the distilled water and boiled 100 recorded the shortest plants recorded 71.00 and $71.33 \mathrm{~cm}$. Moreover, similar results were obtained in the second season. These findings were in agreement with Abdalla (2013) which considered the increase in plant length in rocket (Eruca vesicaria sub sp. sativa) plants due to the fertilization with the MLE. In addition, this may be due to its high component from $\mathrm{N}$ percentage which has been shown inTable (1).

Regarding the effect of MLE type and concentration on the branches number, data in the same Table (3) clear that all of the cold extracts concentration giving a positive increment in this parameter than the other extraction method (boiled extract) in both seasons, as it was the superior in gaving values ranged from 27.00 to $31.67 \mathrm{branch} / \mathrm{hill}$ and the other one ranged from 20.33 to $21.67 \mathrm{branch} / \mathrm{hill}$. Similar results were obtained during the second season, since it was obvious that insignificant differences were shown inside most of the cold extract concentrations $(25,50$, and $75 \%)$. On contrast, the lowest branches number value recorded using the boiled MLE at $75 \%$.

Similar trends which obtained with the plant height and the branches number were also observed with the herb dry weight, as the data in same Table (3) show 25.20 and 26.88 or 26.34 and 27.95 g/herb dry weight/hill, during the first and the second season by using $100 \%$ cold and boiled extract, respectively. It was obvious that the boiled moringa leaf extract was the superior to the other treatments in this parameter. This result matches with Mishra et al., (2013). In addition, the control plants in the two examined season, significantly recorded the lowest values of 17.05 and $18.69 \mathrm{~g} / \mathrm{hill}$, respectively when compared with most of the other treatments. In a similar way Balakumbahan and Rajamani (2010), Prabhu et al., (2010) recorded similar results when they applied the MLE at 2 or $4 \%$ on senna plants and sacred basil, respectively. As they concluded that spraying $2 \%$ of MLE was more effective than $4 \%$ and raised all the measured growth parameters above the control plants (plant height, dry weight, branches number). The reason for this acceleration of growth may be due to the high content of moringa leaf 
extracts from the crude proteins (43.5\%) and the growth promoting hormones like auxins and cytokinins Moyo et al., (2012) and Makkar and Becker (1996). In addition, it was known that the proteins are essential for formation of the protoplasm, while the growth hormones favored rapid cell division, cell multiplication and enlargement

Table 3. Effect of different extraction methods and concentrations of moringa leaf extract on plant height $(\mathrm{cm})$, branches number/hill and herb dry weight (g)/ hill.

\begin{tabular}{lccccccc}
\hline $\begin{array}{l}\text { Moringa } \\
\text { extract } \\
\text { Method }\end{array}$ & \multicolumn{4}{c}{$\begin{array}{c}\text { Plant height } \\
\text { (cm) }\end{array}$} & $\mathbf{1}^{\text {st }}$ & $\mathbf{2}^{\text {nd }}$ & \multicolumn{2}{c}{$\begin{array}{c}\text { Branches } \\
\text { number/ hill } \\
\mathbf{1}^{\text {st }}\end{array}$} & \multicolumn{2}{c}{$\begin{array}{c}\text { Herb dry } \\
\text { weight }\end{array}$} & $\mathbf{1}^{\text {st }}$ & $\mathbf{2}^{\text {nd }}$ \\
\hline Control & 0 & 71.33 & 73.33 & 26.67 & 25.33 & 17.05 & 18.69 \\
\hline \multirow{4}{*}{ Cold } & 25 & 78.33 & 93.67 & 27.00 & 29.00 & 18.14 & 19.81 \\
& 50 & 85.00 & 76.67 & 29.33 & 31.67 & 20.56 & 22.06 \\
& 75 & 84.33 & 86.67 & 30.76 & 28.67 & 22.83 & 24.44 \\
& 100 & 88.67 & 101.33 & 31.67 & 21.67 & 25.20 & 26.88 \\
\hline \multirow{4}{*}{ Boiled } & 25 & 82.33 & 87.67 & 20.33 & 22.67 & 19.40 & 22.69 \\
& 50 & 85.33 & 88.67 & 21.67 & 20.33 & 21.75 & 23.22 \\
& 75 & 79.67 & 90.67 & 20.33 & 19.00 & 24.04 & 25.74 \\
& 100 & 71.00 & 84.67 & 21.00 & 20.67 & 26.34 & 27.95 \\
\hline L.S.D at 5\% & 7.25 & 6.59 & 6.59 & 4.64 & 0.18 & 1.65 \\
\hline
\end{tabular}

\section{Fruit parameters:}

Data in Table (4) clear that 50 and $100 \%$ cold extract significantly recorded the highest values $(73.33$ and 79.17) in the first season and (79.16 and 78.30) in the second season than all treatments. It could be observed that spraying the cold extract at all concentrations used produced the highest values than the boiled extracts

Concerning data in the same Table (4) it was obvious that spraying the cold MLE at $100 \%$ produced the heaviest fruits yield g/hill recording 37.51 and 32.51 $\mathrm{g} /$ hill followed by the values of the cold MLE at 50 and $75 \%$ recording values ranged from 34.04 to $26.56 \mathrm{~g}$ /hill with insignificant differences between them. On the other hand, the boiled MLE at 25\% recorded the lowest value in the first season and the cold one recorded the lowest in the second season in that characteristic comparing with the others.

Table 4. Effect of different extraction methods and concentrations of moringa leaf extract on umbels number/hill, fruits yield (g)/hill and seed index of coriander plant in the two seasons.

\begin{tabular}{lccccccc}
\hline $\begin{array}{l}\text { Moringa } \\
\text { extract } \\
\text { Method }\end{array}$ & \multicolumn{4}{c}{$\begin{array}{c}\text { Umbels } \\
\text { number /hill } \\
\mathbf{1}^{\text {st }}\end{array}$} & \multicolumn{2}{c}{$\begin{array}{c}\text { fruits yield } \\
\mathbf{( g ) / h i l l}\end{array}$} & \multicolumn{2}{c}{$\begin{array}{c}\text { Seed } \\
\text { index } \\
\mathbf{1}^{\text {st }}\end{array}$} & $\mathbf{2}^{\text {nd }}$ & $\mathbf{1}^{\text {st }}$ & $\mathbf{2}^{\text {nd }}$ \\
\hline Control & 0 & 61.67 & 63.33 & 23.11 & 20.95 & 7.64 & 7.64 \\
\hline \multirow{4}{*}{ Cold } & 25 & 67.50 & 72.50 & 21.89 & 20.23 & 8.74 & 8.72 \\
& 50 & 73.33 & 79.16 & 34.04 & 26.56 & 10.19 & 9.44 \\
& 75 & 67.67 & 71.66 & 33.09 & 30.51 & 9.76 & 10.12 \\
& 100 & 79.17 & 78.30 & 37.51 & 32.51 & 9.93 & 10.63 \\
\hline \multirow{3}{*}{ Boiled } & 25 & 50.83 & 56.66 & 21.51 & 26.00 & 8.11 & 8.05 \\
& 50 & 54.16 & 50.83 & 30.64 & 24.21 & 8.77 & 8.70 \\
& 75 & 50.83 & 47.50 & 30.30 & 28.11 & 11.44 & 11.83 \\
& 100 & 52.50 & 51.66 & 27.30 & 27.05 & 8.82 & 8.56 \\
\hline L.S.D at 5\% & 9.16 & 11.92 & 7.71 & 8.05 & 2.66 & 2.75 \\
\hline
\end{tabular}

Concerning 1000 fruits weight, data in Table (4), clear that spraying the boiled MLE at $75 \%$ produced the highest values of $11.44,11.83$ during the first and the second season, respectively followed by the values of the cold MLE at 50, 75, 100\% with no significant difference between them. Similar results were obtained during the second season. In general, it could be observed that most of the other extract concentrations had an insignificant difference between them in this parameter. While the control plant produced the lowest values during the two seasons in this character. The fruits weight increase in plants sprayed with a foliar application of MLE was probably due to the presence of high endogenous levels of cytokinins like zeatin, kinetin, etc. resulting in the increase of the fruit size and the number of the umbel. MLE contains major and minor nutrients, amino acids, vitamins, and also cytokinins, auxins, and abscisic acid (ABA) like growth substances Foidle et al., (2001). This finding may be due to the potential promoting process of the moringa on the vegetative growth and the fruit yield Mohamed et al., (2013) and Azra et al., (2013).

\section{3: Chemical constituents:}

Data in Table (5) indicate that applying the foliar spray of the boiled MLE at a concentration of $100 \%$ significantly produced the highest values of nitrogen percentage $4.33,4.24$ on the first and the second seasons, followed by the values of $4.23,4.15$ with using the cold MLE at $100 \%$. On contrast, the lowest value of $\mathrm{N} \%$ was recorded by using the control in the both seasons. It could be observed an ascending increase in the nitrogen percentage by increasing the concentrations of the moringa extract in the two extraction methods.

Concerning data in the same Table (5) indicate that applying the foliar spray of the boiled or the cold MLE at a concentration of $100 \%$ significantly produced the highest values of phosphors 0.52 on the first season. On the other side, the lowest $\mathrm{P}$ percentage recorded by the control in both seasons $(0.46$ and 0.43$)$. This may be a result of moringa high content from the essential minerals such as $\mathrm{Ca}, \mathrm{Mg}, \mathrm{K}, \mathrm{Fe}, \mathrm{Zn}, \mathrm{P}, \mathrm{S}, \mathrm{Cu}, \mathrm{Mn}, \mathrm{Se}$ and $\mathrm{Na}$ which can be valorized for a balanced nutrition of plants Moyo et al., (2011) and Yameogo et al., (2011).

Table 5. Effect of different extraction methods and concentrations of moringa leaf extract on $\mathbf{N}$ $\mathrm{P} \mathrm{K \%}$ of Coriander plant in the two seasons.

\begin{tabular}{|c|c|c|c|c|c|c|c|}
\hline \multirow{2}{*}{$\begin{array}{l}\text { Moringa } \\
\text { extract } \\
\text { Method }\end{array}$} & \multirow[b]{2}{*}{$\%$} & \multicolumn{2}{|c|}{ N\% } & \multicolumn{2}{|c|}{ P\% } & \multicolumn{2}{|c|}{$\mathrm{K} \%$} \\
\hline & & $\mathbf{1}^{\text {st }}$ & $2^{\text {nd }}$ & $1^{\text {st }}$ & $2^{\text {nd }}$ & $1^{\text {st }}$ & $2^{\text {nd }}$ \\
\hline \multirow[t]{3}{*}{ Control } & 0 & 3.70 & 3.55 & 0.46 & 0.43 & 4.40 & 4.61 \\
\hline & 25 & 3.76 & 3.66 & 0.46 & 0.44 & 4.52 & 4.75 \\
\hline & 50 & 3.93 & 3.81 & 0.49 & 0.46 & 4.68 & 4.95 \\
\hline \multirow[t]{4}{*}{ Cold } & 75 & 4.04 & 3.96 & 0.50 & 0.47 & 4.83 & 5.08 \\
\hline & 100 & 4.23 & 4.15 & 0.52 & 0.49 & 4.97 & 5.26 \\
\hline & 25 & 3.86 & 3.74 & 0.47 & 0.45 & 4.58 & 4.86 \\
\hline & 50 & 3.99 & 3.90 & 0.49 & 0.47 & 4.72 & 5.00 \\
\hline \multirow[t]{2}{*}{ Boiled } & 75 & 4.16 & 4.08 & 0.51 & 0.48 & 4.92 & 5.18 \\
\hline & 100 & 4.33 & 4.24 & 0.52 & 0.50 & 5.07 & 5.26 \\
\hline \multicolumn{2}{|c|}{ L. S.D at $5 \%$} & 0.08 & 0.07 & 0.01 & 0.01 & 0.07 & 0.07 \\
\hline
\end{tabular}


Regarding the effect of MLE type and concentration on $\mathrm{K}$ percentage, data in Table (5), show that the increase in $\mathrm{K}$ percentage values was combined with the increase in the concentration of the moringa extract in the two extraction methods. So the highest percentage of 5.07 and $4.97 \%$ were recorded by using the boiled MLE and the cold MLE at $100 \%$ in the first season, respectively and the same results were shown in the second season since the highest percentage of 5.26 was recorded by using the boiled and cold MLE at $100 \%$. Several comparable studies confirmed the current data. For instance, Schuphan (2005), Noori et al., (2010), Sivakumar and Ponnusami (2011) and Abdalla and El-Khoshiban (2012) realized the increment uptake and accumulations of some nutritive elements as $\mathrm{N}, \mathrm{P}, \mathrm{K}, \mathrm{Ca}, \mathrm{Mg}$ as well as $\mathrm{Fe}$ in roots and shoots of several plants under investigation as a consequence of organic fertilization from different sources (plant and animal source) including MLE.

As for effect of the moringa leaf extraction methods and their concentrations on total carbohydrates and chlorophyll, data in Table (6) showed that using the boiled method at $100 \%$ produced the highest value of total carbohydrates of $48.65 \%$ followed by the cold extract at $100 \%$ recording $48.39 \%$ in the first season. On contrast, the lowest total carbohydrates percentage of $46.74 \%$ recorded by using the control (distilled water) treatment. Moreover, a similar result with much-closed values was obtained in the second seasons.

Table 6. Effect of different extraction methods and concentrations of moringa leaf on Total carbohydrates and total chlorophyll of coriander plant in the two seasons.

\begin{tabular}{|c|c|c|c|c|c|}
\hline \multirow{2}{*}{$\begin{array}{l}\text { Moringa } \\
\text { Extract } \\
\text { Method }\end{array}$} & \multirow[b]{2}{*}{$\%$} & \multicolumn{2}{|c|}{$\begin{array}{c}\text { Total } \\
\text { carbohydrates\% }\end{array}$} & \multicolumn{2}{|c|}{$\begin{array}{l}\text { Total chlorophyll } \\
\text { (mg/g. f.w) }\end{array}$} \\
\hline & & $1^{\text {st }}$ & $2^{\text {nd }}$ & $1^{\mathrm{st}}$ & $2^{\text {nd }}$ \\
\hline \multirow[t]{3}{*}{ Control } & 0 & 46.74 & 47.97 & 2.53 & 2.64 \\
\hline & 25 & 47.28 & 48.35 & 2.42 & 2.06 \\
\hline & 50 & 47.35 & 48.76 & 2.95 & 3.42 \\
\hline \multirow[t]{4}{*}{ Cold } & 75 & 47.93 & 49.18 & 2.77 & 2.17 \\
\hline & 100 & 48.39 & 49.74 & 2.55 & 2.72 \\
\hline & 25 & 47.28 & 48.42 & 2.61 & 2.51 \\
\hline & 50 & 47.66 & 49.02 & 3.36 & 3.50 \\
\hline \multirow[t]{2}{*}{ Boiled } & 75 & 48.15 & 49.47 & 1.39 & 1.48 \\
\hline & 100 & 48.65 & 49.95 & 1.80 & 1.32 \\
\hline L.S.D 5\% & & 0.35 & 0.18 & 0.46 & 0.51 \\
\hline
\end{tabular}

It was obvious from data in Table (6) that using the boiled MLE at $50 \%$ produced the highest total chlorophyll of 3.36 and $3.50 \mathrm{mg} / \mathrm{g}$. f.w., followed by 2.95 and 3.42 with no significant difference when the cold MLE was used at $50 \%$ in both seasons, respectively. On the other hand, the lowest total chlorophyll content of 1.39 was recorded by using the boiled MLE at $75 \%$, followed by $1.80 \mathrm{mg} / \mathrm{g}$.f.w. in the first season. On contrary, Abou-Zeid and El-Darier (2014) proved that there was an inverse proportional relationship between increasing the severity of different percentages of $\mathrm{M}$. oleifera extract on one hand, and leaves content from chlorophyll a and b, and total chlorophyll on the other hand and this may differ from plant to other. Some reports mentioned that moringa leaf possesses plant nutrients and antioxidants in considerable amounts Yang et al., (2006) and improve the leaf chlorophyll contents under salinity by modulating enzymatic and non-enzymatic antioxidants, total soluble proteins, increased leaf $\mathrm{K}$ contents with decreased $\mathrm{Na}$ and $\mathrm{Cl}$ Azra et al., (2013). Moreover, the foliar application of moringa extracts prevents the premature leaf senescence and resulting in more leaf area with higher photosynthetic pigments Rehman and Basra (2010).

Data presented in Table (7), show the effect of the two methods of moringa leaf extract on essential oil percentage. Such data clearly indicate that the percentage of the essential oil had significantly affected by increasing the concentration in the two methods of extraction, since the superior values was obtained by using cold and boiled extract at $75 \%$ and $100 \%$ with insignificant differences between them during the two seasons. The increment in essential oil yield might be due to the increase in vegetative growth, nutrients uptake or changes in the size of vittae in fruits and monoterpenes biosynthesis. In accordance, essential oil yield of Coriandrum sativum increased with increasing rates of $\mathrm{N}$ and $\mathrm{P}$ application Tiwari and Banafar (1995).

Table 7. Effect of different extraction methods and concentrations of moringa leaf on the essential oil $(\%) / 100(g)$ dry seeds of coriander plant in the two seasons.

\begin{tabular}{lccc}
\hline $\begin{array}{l}\text { Moringa extract } \\
\text { Method }\end{array}$ & Conc. & \multicolumn{2}{c}{ Essential oil\% } \\
$\mathbf{1}^{\text {st }}$ & $\mathbf{2}^{\text {nd }}$ \\
\hline Control & 0 & 0.10 & 0.08 \\
\hline \multirow{3}{*}{ Cold } & 25 & 0.10 & 0.10 \\
& 50 & 0.10 & 0.10 \\
& 75 & 0.20 & 0.18 \\
& 100 & 0.30 & 0.27 \\
Boiled & 25 & 0.10 & 0.10 \\
& 50 & 0.10 & 0.10 \\
L.S.D 5\% & 75 & 0.19 & 0.07 \\
& 100 & 0.28 & 0.30 \\
\hline
\end{tabular}

GLC analysis of the fruits volatile oils was illustrated in Table (8), Figures (1 to 5) which indicated that $\alpha$-pinene, $\beta$-pinene, p-cymene, linalool, geranial, borneol, linalyl acetate, and geranyl acetate were identified in all treatments. Linalool was the main component in all the tested treatments as it showed the highest values in relation to the other components. The highest percentage of linalool was obtained from the boiled MLE at 75 or $100 \%$. $\alpha$-pinene was higher when the cold MLE at $100 \%$ was used. Although, the clod MLE at $75 \%$ recorded the superior values in some components like $\beta$-pinene, $\mathrm{p}$-cymene, and geranial even the components of borneol recorded 4.94 in a case of using the cold method at $100 \%$ and the same recorded the highest in Linalyl acetate followed by the boiled MLE at $75 \%$. Geranyl acetate is known in all of the cold and the boiled treatments except the cold or the boiled $100 \%$. 
Table 8. Effect of different extraction methods and concentrations of moringa leaf on the essential oil components in dry seeds of coriander plant.

\begin{tabular}{|c|c|c|c|c|c|}
\hline \multirow{2}{*}{$\begin{array}{l}\text { MLE methods } \\
\text { Components }\end{array}$} & \multirow{2}{*}{$\begin{array}{c}\text { Control } \\
\text { (D.W) }\end{array}$} & \multicolumn{2}{|c|}{ cold } & \multicolumn{2}{|c|}{ Boiled } \\
\hline & & $75 \%$ & $100 \%$ & $75 \%$ & $100 \%$ \\
\hline$\alpha$-pinene & $r . \leqslant r$ & r.YT & $r . \leqslant \varepsilon$ & $1 . \leqslant 9$ & 2.33 \\
\hline$\beta$-pinene & 1.07 & r. . & $1.0 \mathrm{~V}$ & $1 . \varepsilon r$ & 1.51 \\
\hline p-cymene & I.r & $r .74$ & r & $1 . r$ & 1.30 \\
\hline Linalool & VA.rv & VI.VT & VA.T & A. ro & 83.61 \\
\hline Geranial & r.q1 & $r . \wedge$ & r.l. & r.91 & 2.97 \\
\hline Borneol & $r .9$ & r.IV & $\leq .9 \leq$ & $r .17$ & 2.20 \\
\hline Linalyl acetate & $\varepsilon .9$. & $\Sigma . \vee T$ & ז.7.7 & $0 . \cdot r$ & 4.99 \\
\hline Gernyl acetate & r.7. & r.r. & - & r.v. & - \\
\hline Known & $91 ., \leq \leqslant$ & $90 . \leqslant 9$ & 91.74 & $q \wedge . r 4$ & 98.91 \\
\hline
\end{tabular}

Generally, the active reaction of moringa leaf extract on the vegetative growth, fruit parameters and the chemical components of the coriander plant may be due to its nutrients content. As a medicinal plant, the leaves extracts of $\mathrm{M}$. oleifera provides a rich and rare combination of zeatin Anjorin et al., (2010)



Figure 1. G.L.C. chromatogram analysis of coriander oil constituents (\%) on the control (D.W).

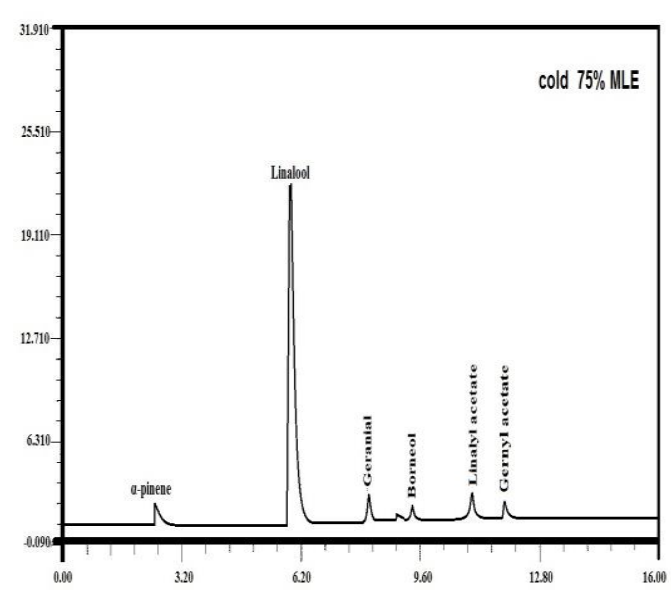

Figure 2. G.L.C chromatogram analysis of coriander oil constituents on the cold MLE extract $75 \%$.

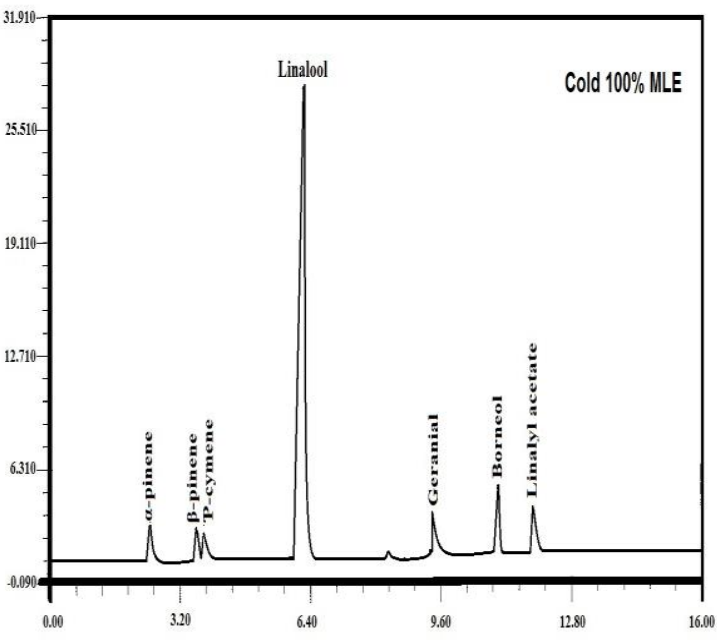

Figure 3. G. L.C. chromatogram analysis of coriander oil constituents on the cold MLE extract $100 \%$.

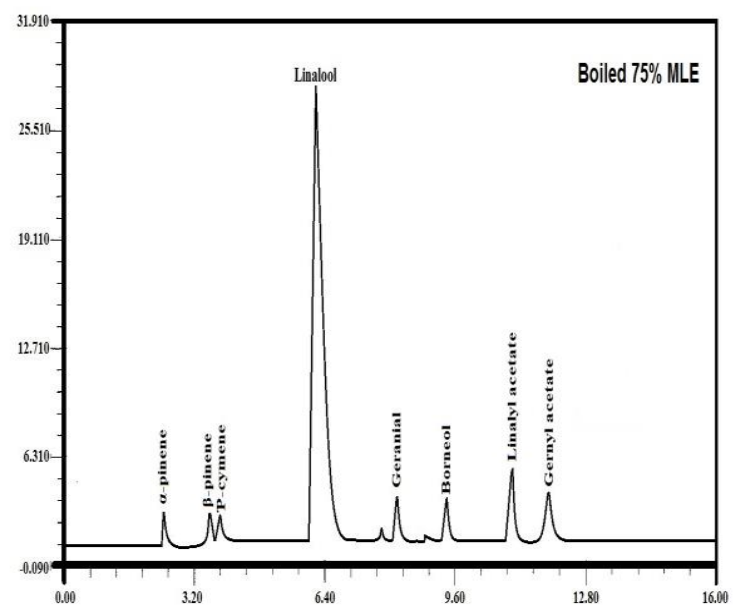

Figure 4. G.L.C chromatogram analysis of coriander oil constituents on the boiled MLE extract $75 \%$.

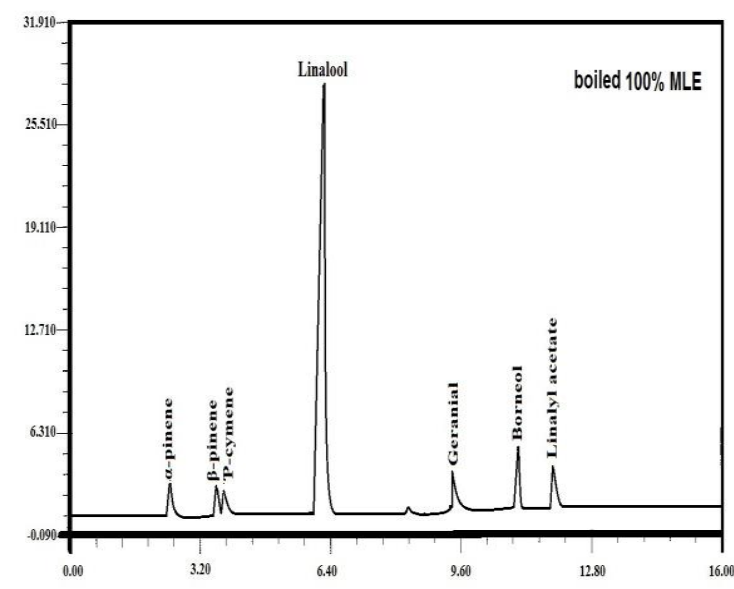

Figure 5. G.L.C. chromatogram analysis of coriander oil constituents on the boiled MLE extract $100 \%$. 


\section{REFERENCES}

A. O. A. C. (1984). Official methods of analysis $13^{\text {th }}$ ED. Published by the Association of Official Analytical Chemists. Washington. Dc. U.S.A

Abdalla, M. M. (2013). The potential of Moringa oleifera extract as a biostimulant in enhancing the growth, biochemical and hormonal contents in rocket (Eruca vesicaria subsp. sativa) plants. Int. J. Plant Physiol. Biochem. 5(3): 42-49.

Abdalla, M. M. and El-Khoshiban, N. (2012). The palliative effect of bio-organic fertilizer on lead pollution in Lycopersicum esculentum plants. J. Basic App. Sci. 8:1-12.

Abou-Zeid, H. M. and El-Darier, S. M. (2014). Biological interactions between Moringa oleifera Lam. and two common food intercrops: growth and some physiological attributes. International Journal of Advanced Research, 2, (6): 823-836.

Anjorin, T. S.; Ikokoh, P. and Okolo, S. (2010). Mineral composition of Moringa oleifera pods and seeds from two regions in Abuja, Nigeria. J. Agric. Biol., 12(3): 431-434.

Azra, Y.; Basra, S.; Farooq, M.; Rehman, H.; Hussain, N. and Athar, H. (2013). Exogenous application of moringa leaf extract modulate the antioxidant enzyme system to improve wheat performance under saline conditions. Plant Growth Regul. 69:225-233.

Balakumbahan, R. and Rajamani, K. (2010). Effect of bio stimulants on growth and yield of senna (Cassia angustifolia var.KKM.1). J. Hort. Sci. and Ornamen. Plants, 2(1): 16-18.

British Pharmacopoea (2000). Determination of Volatile Oil in Drugs. The Pharmaceutical press. London. pp. 1914.

Foidl, N.; Makkar, H. P. S. and Becker, K. (2001). The potential of Moringa oleifera for agricultural and industrial uses. In: The Miracle Tree: The Multiple Attributes of Moringa, pp: 45-76. (Lowell J. Fuglie, ed.), CTA, Wageningen The Netherlands.

Fuglie, L. J. (1999). The Miracle Tree: Moringa oleifera. p. 68. In Natural nutrition for the tropics. Church World Service, Dakar, Senegal.

Fuglie, L. J. (2000). New Uses of Moringa Studied in Nicaragua. p. 68. In ECHO Development Notes biomasa@ibw.com.

Gomez and Gomez (1984). Statistical Procedures. Agric. Res. 2nd Ed. Johnwiley and Sons, Inc, New York, USA

Jackson, M. L. (1973). Soil Chemical Analysis. prentichall of india-private, new delhi, pp. 144-197.

Mackinney, G. (1941). Absorpation of light by cholorphyll solution. J. Bio. Chem., 140:315-332.

Makkar, H. P. S. and Becker, K. (1996). Nutritional value and antinutritional components of whole and ethanol extracted Moringa oliefera leaves. Anim. Feed Sci. Tech. 63: 211-228.
Melo, E. D. A.; Bion, F. M.; Filho, J. M. and Guerra, N. B. (2003). In vivo antioxidant effect of aqueous and etheric coriander (Coriandrum sativum L.) extracts. European Journal of Lipid Science and Technology 105: 483-487.

Mishra, S. P.; Pankaj, S.; Sanjay, S.; Rameshwar, D. and Prasad, R. S. (2013). Moringa oleifera leaf extract as biostimulant for increasing pea yield. Indian Forester. 139(6): 562-563.

Mohammed, R.; Olorukooba, M. M.; Akinyaju, M. M. and Kambai, E. A. (2013). Evaluation of different concentrations and frequency of foliar application of Moringa extract on growth \& yield of onion, Allium cepa Lam. Agro search. 13(3):196-205.

Moyo, B.; Masika, P. J.; and muchenje, v. (2012). Antimicrobial activities of Moringa oleifera Lam. leaf extracts, African Journal of Biotechnology. 11(11):2797-2802.

Nouman, W.; Siddiqui, M. T., and Basra, S. M. A. (2012).Moringa oleifera leaf extract: Aninnovative priming tool for rangeland grasses. Turk. J. 35.

Noori, J. M.; Ardalan, M. M.; Nezami, M. T.; Cherati, A. and Alizadeh, G. (2010). Effect of organic fertilizers (compost Amol, vermicompost, animal manure) and manganese on chlorophyll concentrations and some of nutrient concentrations of soybean (Glycine $\max$ L). OFIS Conferences, Islamic Azad Univ of Bonjord. Karaj Branch. pp.18-27.

Petrerburgski, A. V. (1968). Hand book of agronomic chemistery .kolas publishing Hous, Moscow, (in Russian), pp. 29-86.

Phiri, C. (2010). Influence of Moringa oleifera leaf extracts on germination and early seedling development of major cereals Agriculture and Biology Journal of North America. 1(5):774-777.

Prabhu, M.; Kumar, A. R. and Rajamani, K. (2010). Influence of Different Organic Substances on Growth and Herb Yield of Sacred Basil (Ocimum Sanctum L.). Indian J. Agric. Res., 44 (1): 48 52.

Ramadan, F. M. and Morsel, J. T. (2002). Oil composition of coriander (Coriandrum sativum L.) fruit-seeds. Eur. Food Res. Technol. 215: 204-209.

Rehman, H. and Basra, S. M. A. (2010). Growing Moringa oleifera as a multipurpose tree; some agro-physiological and industrial perspectives. American Chronicle Web. http://www. americanchronicle. com/articles/view/159447. Accessed 28 November.

Sadasivam, S. and Manickam, A. (1996). Bio chemical methods, $2^{\text {nd }}$ Ed.New age inter. India.

Schuphan, W. ( 2005). Nutritional value of crops as influenced by organic and inorganic fertilizer treatments. Plant Foods Hum. Nutr. 23(4): 333358. 
Sivakumar, V. and Ponnusami, V. (2011). Influence of spacing and organics on plant nutrient uptake of Solanum nigrum. Plant Arch. 11(1): 431-434.

Smallfield, B. M.; van klink, J. W.; Perry, N. B. and Dodds, K. G. (2001). Coriander spice oil: Effects of fruit crushing and distillation time on yield and composition. Journal of Agricultural and Food Chemistry 49: 118-123.
Yameogo, C. W.; Bengaly, M. D.; Savadogo, A.; Nikiema, P. A. and Traore, S. A. (2011). Determination of chemical composition and nutritional values of Moringa oleifera leaves. Pak. J. Nutr. 10(3):264-268.

Yang, R. Y.; Tsou, S. C. S.; Lee, T. C.; Chang, L. C.; Kuo, G. and Lai, P. Y. (2006). Moringa, a novel plant rich in antioxidants, bioavailable iron, and nutrients. In: C. T. Ho (ed) Challenges in Chemistry and Biology of Herbs. American Chemical Society, Washington, D.C. $224-239$.



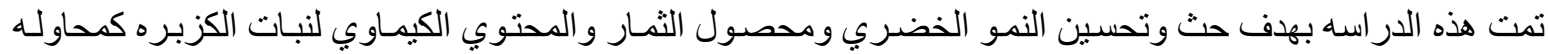

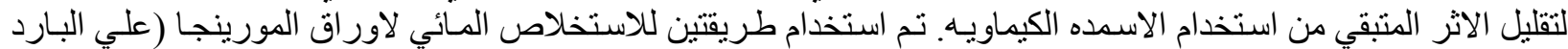

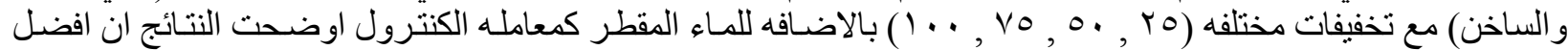

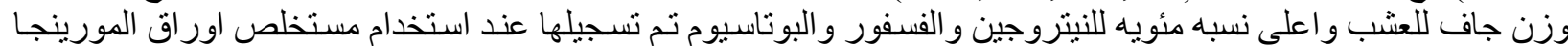

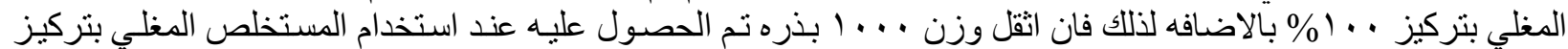

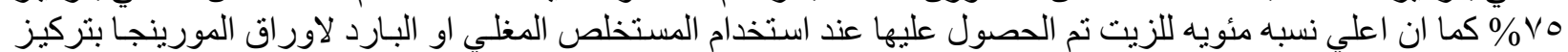



